\title{
The patriotic poetry of Adrian Păunescu. An experiment of reframing history
}

\author{
Drd. Anamaria MIHĂIL $\breve{A}$ \\ Universitatea din Cluj-Napoca
}

\begin{abstract}
In her article "The patriotic poetry of Adrian Păunescu. An experiment of reframing history" Mihăilă Anamaria discusses the different aspects showed by the patriotic poetry of Adrian Păunescu, especially after 1989, but in comparison with its anterior forms. Following the concepts of Maurizio Viroli, this work intends to demonstrate the permanency of ideology in writing and critical reception, framing the historical truth and the problem of ethic view. The patriotic theme shows the social imperatives and the rhetorical changes in addition to the époque. Păunescu's essays of "automistification", his "censored" volumes or the interviews and the documents hidden by the Party and illustrated after 1990 prove, at the end, a modus vivendi under communism.
\end{abstract}

Keywords: Adrian Păunescu, refraiming history, patriotic poetry.

Adrian Păunescu is one of the most representative figures of politically involved poets in after war literature, more precisely in neo-modernism. His social attitude is totally different from the poets of the generation because of the attitude he has face to the communists. His militant poetry as well as his submissive writing is relevant in this sense. The aim of this paper is to find out the centres of tension of Păunescu's poetry by analyzing the patriotism of his work in the period of communism and after the regime. In fact, we try to argument that Păunescu's reception was often influenced by his political position. At the time, the poet himself uses patriotism as an instrument of resistance. Reframing history, in the present text, means selecting the favorable aspects needed for reconfiguring a compromise portrait. Adrian Păunescu, as we will show in the text below, selects patriotism as justification in the context of political changes before, but especially after 1989 . 
The reception of Adrian Păunescu's poetics has been strongly affected by political factors, undoubtedly illustrating a massive ideology. Nevertheless, the term "ideology" does not necessarily require association with militancy or ferocious anticommunism as extremes of manifestation. In this context, it should be understood as "abjection" (Rivette, "De l'abjection" 54-55) of the historical truth, from one direction to another. Thus, in this category of ideologies, we find receptions which, convinced by the plausibility of affirmations, do not leave room for relativism, being either confirmed or disputed.

Scrutinized by Mircea Popa's ethical criteria (Popa, Prezențe literare 12) and Ion Rotariu's non-restrained appreciation (Rotariu, Postfaţă... 12), the critics who analyzed Păunescu's texts often ignored intermediary alternatives of interpretation. Those who have tried to separate themselves from the political factor have fallen into the other extremist ideology, respectively they gained the conviction that their judgment is "rightful" due to their neutrality. So, exegetes such as Cornel Moraru (Moraru, Semnele realului... 42), who only analyzes the text from aesthetic perspective, sabotages with equal contribution to the historical truth, for it detaches poetry entirely from the context it was written and the problems of an era. Even so, Păunescu's poetry holds valuable significance because of the various ways of writing and employment (before 1989) as well as his aesthetic reorientation (after 1989).

After the creation of Flacăra Cenacle in September 1973 that was patronized three years later by the festival Cântarea României, Păunescu risked to compete against the leader's figure. Becoming a threat to a closed system, the cenacle was abolished in 1985, after the Security stirred a fire at the Ploiești stadium, where the meeting with the readers was bound to happen (Cernat, $\hat{I} n$ căutarea comunismului pierdut 264). Banning Păunescu's courageous opinions proved to be, once again, incomplete and unfair. In the competition of the two myths, of the bard-poet and the wise ruler, the former yields in order to make room for the latter.

Along with the History of a second / Istoria unei secunde, in 1971, the historical year of July Theses / Tezele din Iulie, when the policy of Ceaușescu became authoritative, the manner of interlinking with the homeland and the sections of occasional genres, such as the anthem or ode, became more and more frequent. His movements in political and aesthetic plans were not innocent at all and corresponded to switches in political changes. The rhythm, with a few variations modifies its nuance in Manifest for the gound's health / Manifestul pentru sănătatea pământului, was published in 1980, in order to return to previous 
implications a year later, with the poem Great times / Mărețe vremi, a gesture of revolt which is always suspended.

Without doubt, the subversive insertions in Păunescu's texts exist, at least at a declarative level. The poems from Manifest for the ground's health / Manifest pentru sănătatea pământului allow expressions deemed too strong to escape from the eyes of political officials, which question either the vigilant censorship, either the authenticity of poetic gesture. However, the 90's were remarkable through configuring a new generation, which challenged the writer's popularity, exactly through the alternative ideology, pro-occidental and democratic. In this context, Păunescu's manifestations in front of dictatorship risked to occur amid the attempt to solidify the population gained during the Flacăra Cenacle. Some of the verses found in this volume are as equally dangerous for the communist regime, as the ones found in the censored volume. Enchanting as an illusion of freedom of expression and fuelling the fascination of anticommunism writing, the regime allowed the apparition of "subversive" volumes, right when an antinationalist current, with a consolidated ideology threatens the status quo.

Therefore, the volume Censored poetry / Poezii cenzurate, published right after 1989, proves to be problematic right from the start. If Corina Croitoru tends to see the audiences' selections as random, without a specific logic, the premises of the present work are that because of social pressure caused by the historical tribunal exchange, because of the desire for ethical vindication and coming in terms with the victim status, the texts published in 1990, are most likely, selfcensored (Croitoru, Politica ironiei în poezia românească sub comunism 154). Selfcensorship functions as a form of self-defense in front of many accusations brought by ethical criteria, through assumption of co-belligerence. Moreover, the thematic changes and the relationship with patriotism in the texts published after the Revolution correspond to attempts to adapt to a reality which drastically changes point of views and the criteria of appreciation of literature. 
Like this, the poet's efforts post-1989 coincide with his attempts of recovering his previous position of authority, of becoming the focus once again through a different context, manipulated through image: Păunescu's postDecember poetry, in concordance with his attitude in the political and cultural, the schematic patriotist parade before 1971 and fulminant in the next era, the figure of "hawk of the country", which he promoted at a mature age in interviews and declarations, denying a triumphant lyric of periodicals in anthologies build, the portrait of an uncommon man, and of a few historical realities which will be often disguised.

In Maurizio Viroli's vision (Viroli, Din dragoste pentru patrie 163), the first necessary delamination before discussing a patriotic theme in Păunescu's lyric was the one between patriotism and nationalism. The disassociation between the two implies a permanent game between militants and different forms of employment. From the start, it's obvious that this poem can't be discussed unless it's in relation with political context, to the social universe in which it is written and which it reacts. The first two volumes of Păunescu, the volume Overfeelings / Ultrasentimente published in 1965 and The first lambs / Mieii primi published in 1966 already situated him among the generation's most important poets. In fact, the favorable reception continued in the next period as well, once he publishes the volume The sleepy fountain / Fântâna somnambulă in 1968. Right from the begining, the poet widened the frame and increases the details until exhaustion, building poetry around the variations of the same subject. In terms of Mircea Popa, Păunescu is a "slump poet", born for times of affliction in literature and history, a poet of reaction, always in relation with contemporaneity (Popa, Prezențe literare 187).

Like most of his congeners, he took over Blaga's poetic model, especially in the first volume. Thus, his relationship with homeland was established through an attempt to return to origins, in which childhood and village contribute to an ideal age. On the other hand, the debut find correspondence especially in the denunciation of incarnation and in the detachment of the fetal body, through The snatch from parents / Smulgerea din părinți, a moment which triggered a segmentation of the ages - the age of innocence and the age of acquiring one's own body. Beyond the thematic recurrences of Blaga's lyrics, Păunescu's poetry found the direction circumscribed by the leader of the generation, Nicolae Labiș, as "an expression of a lucid conscience oriented towards the realities of time” („expresia unei conștiințe lucide orientate către realitățile vremii") (Pop, Lecturi fragmentate 81), without illustrating major changes in the volumes until 1971. 
Up until Sir Tudor / Domnul Tudor, of The first lambs / Mieii primi volume, the homeland theme and the specific rhetoric are rather sketched. Along with this, the poet made the transition towards increasingly open poetry, with thick accent on social order and political order. The image of a national hero, built through a speech similar to a preromantic, close to the 48 's exhortations presents the first sign in mutations of expression: “ $\mathrm{O}$, there won't be a winter; the country has been passed by Tudor. / The horse waved its hooves and counties passed / Vladimirescu withered through the air, god of many / Stars above us, that burn in the universe” („O, n-o să mai fie iarnă, a trecut prin țară Tudor. / Calul flutura copite și județe-avea în mers. / A trecut Vladimirescu viu prin aer, zeul multor / Stele de deasupra noastră, care ard în univers") (Păunescu, Manifest pentru sănătatea pământului 46). The portrait of a national hero is defined, in other words, in recognizable terms, by intertextual references to Eminescu's poetics: "He slid down with his horse, smiled, and said nothing"/ "I laughed and said nothing” („El a lunecat cu calul, a surîs, n-a spus nimica"/ „Eu am rîs, n-am zis nimica"). The romantic "laughter" is reduced for Păunescu from a schematic "smile" to an imitative form, illustrating the decay in time and the denunciation of history. The exemplification of a hero and the model of a national poet intuited in the verses of the current volume increased their expressions in later texts.

Starting with the volume entitled The history of a second / Istoria unei secunde in 1971, the opinions of literature criticized diversify. Compared to previous poems, poetry changed its angle towards political and social dimension of existence. Firstly, this is evidenced by increased weighting of patriotic themes, hymns and odes, the recourse of historical models. Once taking a closer look however, the changes in Păunescu's poetry take place on the background of a nationalist-extremist policy suggested by Nicolae Ceaușescu after his return from China. Without necessarily conditioning the aesthetic form from the politic one, the chronological approach of the events doesn't seem to be ignored, more so since the entire generation of the ' 60 's is defined around such movements. Thus, Daniel Cristea-Enache noted that since the autoscopic, hermetic debut, poetry opens up further towards one's self external investigation: "Through a recoiled movement, Păunescu's creations returned to a pre-modern era of Romanian poetry, to the immaculate and grandiloquent 48 's, animated by social and national ideals. In order to enlighten and educate the audience, poetry must be accessible and epic once again, oriented towards moralizing conclusions, remarkable and as much as quantitative as possible. It's easy to distinguish Păunescu's new poetry, the kind that attracted many readers 
and admirers to his side" („Printr-o mișcare de recul calculat, creația lui Adrian Păunescu s-a întors la o vârstă pre-moderna a poeziei românești, la acel pașoptism grandilocvent și curat, animat de idealuri sociale și naționale. Pentru a lumina, a educa publicul cititor, poezia trebuia să fie din nou accesibilă și epică, orientată către concluzii moralizatoare, memorabilă, la propriu, și, de cât mai multe ori, cantabilă. E ușor de recunoscut, aici, noul chip al liricii lui Adrian Păunescu, acela care a atras de partea poetului un numar atât de mare de cititori-admiratori”) (Cristea-Enache, „Râul, Ramul..." 7).

Ever since its first pages, The history of a second / Istoria unei secunde suggested a positioning through writing, premised as "one's own risk" (Păunescu, Istoria unei secunde 5). Rhetorically visible, the text builds a world out of words, like an inflamed form of action through discursive reaction. Hence, the poem Into the long night / In lunga noapte questions where the direction the subversion of the text and the articulation of a deflected homeland are manifested. The suppression of time in the night and the attack of the "old crab" forces unspoken boundaries in the censorship context. Otherwise, one of the editions is sanctioned by the controlling institution, which suspects Păunescu's poetry of content against the regime. Nonetheless, through the text, the references to immediate reality grow weaker, and the subversion rather make references to the Stalinist communism as "bad period" in opposition to a "good" one in the present: "So, through the deep and rainy night / through which you, our country, pass as well,/ in the night of the biggest trespass / in the night of twentieth / when not Bălcescu had been born, but us/ when not Viteazul had been born, but us, / when we woke up in the hollow light / [...] / And then we saw eternity was yours, / That good generates swiftly from bad / that your grace had been born from thee tears / that my kin became thee” (,In lunga și ploioasa noapte deci, / prin care și tu, țara noastră, treci / în noapte marilor fărădelegi / în noaptea secolului douăzeci / când nu Bălcescu se născu, ci noi / când nu Viteazul se născu, ci noi / când ne trezirăm în lumină goi / [...] / Șiatunci vedem că veacul e al tău, / Că binele apare brusc din rău / că harul tău născut a fost din plânsu-ți / că neamul meu ai devenit tu însuți") (Păunescu, Istoria unei secunde 11).

The good-bad dichotomy of the texts which open the volume are overcome, in the following poems, by an observational tone, by a declarative rhetoric which the country no longer pursues, the reconfiguration of a functional territory through individual past or the projection of an invented homeland, but it translates it in terms of Romanian ideology: "Eternal country / unearthly balmy / our children in a river bathe / and the departed in our soil 
bathe / [...] / Here, altogether, lively and dead, / Latinizing under eternal bolts / Count on us! We're staying. We are. Together" („,Tară de veci, nepământesc de caldă / copiii noștri într-un râu se scaldă / și morții noștri în pământ se scaldă / [...]/ Aici, întregi, cu vii ca și cu morți, / latinizând sub veșnicele bolți / Contați pe noi! Rămânem. Sîntem. Toți") (Păunescu, Istoria unei secunde 20). While proliferating cliché expressions and discursive stereotypes, the references towards homeland delimitates, in preromantic style, an idyllic space, a utopia configured in agreement with the impact of official discourse that proposes closing the borders and exacerbating nationalism.

The ambiguity referring to the relation with politics and the social factor is permanently maintained in his poetry. A poem such as Leave us alone / Dați-ne pace doubles its stake and multiplies the possibility of interpretation. Until the end, the poem seems to be the answer to "nation lover" towards any spur to exit the borders. According to the official ideology, this describes "motherland" as a sum of legitimate local spaces, as an identifiable territory: "We love Dîmbovița river, leave us alone / We love Mitropolia hills, leave us alone / We love Pajura building, leave us alone / [...] / we love plausible time, leave us alone / leave us alone, leave us alone” („Noi iubim Rîul Dîmbovița, dați-ne pace, / noi iubim Dealul Mitropoliei, dați-ne pace, / noi iubim Clădirea Pajura / dați-ne pace / [...] / noi iubim timpul probabil, dați-ne pace / dați-ne pace, dați-ne pace") (Păunescu, Manifest pentru mileniul trei 88). The last bit of the poem redefines the hypothesis, the replica being of the "obedient" citizen, who adapts to the external requirements for a decent living.

The appetence for anthem and ode overthrows, as well, the specific meanings of the genres and adds further suspense between politics and aesthetic. Even if Corina Croitoru insists on the active implications of stylistic selection, the obedience form in relation with official discourse, Păunescu's poetry passes, almost, imperceptibly, the border between nationalism and patriotism. Such a text at the limit between engaging for or engaging against the dictatorship is the poem Anthem / Imn, patriotism ensues from the striking root, as a night watch mood, a mood resurrecting stiffened senses: "The head thinks / Bowing / we became unfamiliar with / There's nothing to do, we are safe and sound / There's nothing to do, we are living” („Capul gândește. Plecăciunea / am dezvăţat-o de a fi. / N-avem ce face, sîntem teferi,/ n-avem ce face, sîntem vii") (Păunescu, Manifest pentru mileniul trei 94). Simultaneously, appealing to the species with valency identities, such as doina (Romanian folk song) or ballad, answer in equal measure, to the poet's attempts of expressing, even stylistically, the pathos of patriotic experience. 
A short while after publishing the volume entitled The history of a second / Istoria unei secunde, under the circumstances in which Păunescu's figure was well received by the public, the Flacăra Cenacle was born. Of course, the texts that have metrics and prosody strictly respected (it is not the same thing as fixed form in poetics), frequent in previous volumes, are accessible to a wide audience, for it encourages placing the verses on a song, which makes it easier to remember than others. Built in order to be recited and retained, they become a means of indoctrination. The strategy of formal selection is, in fact, a political strategy: "Writing anthems and prayers set on music, the bard from Bârca allowed a public identity to other singers, and a mythology to solidarize them, and mobilize them emotionally, giving them the feeling of power, unity, dignity and legitimacy.[...] An ordinary man, a man of totalitarian society, indoctrinated with an egalitarian propaganda grafted on a rural extraction mentality, tends to identify with the stereotypes of the affiliation community" („,Scriind imnuri și rugi puse pe muzică, bardul de la Bârca oferea celor cântați o identitate publică și o mitologie care să-i solidarizeze și să-i mobilizeze afectiv, dându-le sentimentul puterii, unității, demnității și legitimității. [...] Omul simplu, omul-masă, îndoctrinat cu o propagandă egalitaristă grefată pe o mentalitate de extracție rurală, tinde să se identifice cu stereotipurile comunității de apartenență") (Paul Cernat, În căutarea comunismului pierdut 265).

In the same context, of the desire to belong in homeland, registers the poetic forms which resort to a common imagination, specific brands, easy to identify. Poems such as Appels from Transilvania / Mere de Ardeal, along with In each Dolj / În câte-un Dolj or Călușarii, which take part of The sleepy fountain / Fântâna somnambulă volume, force local patriotism which pretends recognition points, in attempts of inculcating upon a centric nationalist sentiment, produced even with the price of aesthetic concession in absurd corporations, such as "I wish to be an aviator or călușar (traditional Romanian dancer)” („Aș vrea să fiu aviator sau călușar") (Păunescu, Manifest... 53). In other words, the hero's figure is outbid, once the portrait is repetitively configured through various poems. From the exaltation of Anton Pann's poetry or the glorification of Nicolae Bălcescu, in the presented volume, until Eminescu's poetry which contributed to adding cliché towards the "national poet" myth, Păunescu amplifies lyrical dedications. For him, each heroic gesture, be it more or less significant, corresponds to a poem.

In fact, the registry changes which marked the volume of 1971 are also evidenced through a monstrous look, which requires all the elements in the world, in the smallest details, until exhaustion. The excessive focus also reflects 
across the economistic poetry. In The land for now / Pământul deocamdată, for example, the bookish references, the figure of an exemplary poet and the historical model occupy a good portion of the volume. Between the individual hero (Mircea cel Bătrân) and the collective one (The condition of revolutionary rider / Condiția cântărețului revoluționar), between Sadoveanu, Goga or Bacovia, the differences are eradicated from the poet's ambition to grasp everything. At the same time, the numerous livestock references - be it direct, through dedications or intertextual insertions, or indirect, through an unauthentic style - describe an integrator poetry, which assumes the lyrical beforehand, through the same totalizer logic.

In reversed logic, Păunescu's homeland always lapped over geographic space reconfigured in concordance with the historical past. Romanian interval is delimited in provinces in order to illustrate the unity of country love, the permanent living in the same rhythm. Transylvania (Hill from Transilvania / Colină din Ardeal), Moldavia (Secular Modavia / Moldova seculară) or Wallachia (Valachian fakir / Fachir valah) are "sister" territories in expression and stylistic construction. Indeed, homeland as a collective universe, which recognizes a national identity, is confined in The unrecoverable village / Satul de nerecuperat: "I miss my village as a realm / unrecoverable in memory / To which in vain we crawl / While it's isolated in memory / [...] / I miss my home, deaf, without a space / But my home is time, not only space” („Mi-e dor de satul meu ca de-un tărâm / de nerecuperat în amintire / Spre care în zadar ne mai târâm / Cât el e izolat în amintire / [...] / Mi-e dor de-acasă, surd, fără de sațiu / Dar casa mea e timp, nu numai spațiu") (Păunescu, Manifest... 413). The return to an "unrecoverable village" as a penetration into a known horizon turned unfamiliar illustrates, once again, the evil of the world, of an inadaptable topos which is no longer time, but space. His poetry for mother land and his relation with it is paradoxical in The land for now / Pâmântul deocamdată, "where the militant affection of patriotic poetry: « To be solemn, jovial and hymnal / So I'll be able to sing you, country's land / With the force of love and despair», it cohabits with the ironic distance towards a reality of shortage” („Unde afectarea militantă a poeziilor patriotice: «Să fiu sărbătoresc, voios și imnic / Să pot să te mai cânt, pâmânt al țării / Cu forța dragostei și-a disperării», conviețuiește cu distanțarea ironică față de o realitate a lipsurilor" (Croitoru, Ironia... 151).

In fact, Nicolae Manolescu stated, "more and more often, in the middle of the '70's, Păunescu raised poetry (his and others as well) on the stage of Romania's Singing. Small acts of political courage have been compromised by great cowards, and the claim of truth has been overwhelmed by detestable 
reverences made by the dictatorship and regime. [...] He has admirable poetry, which risked passing by unnoticed because of the preconceived ideas (but how pressed by the author himself), because since The history of a second / Istoria unei secunde, Păunescu has become a monochord poet, empathic and fastidious, unfair with his readers and his own art” („,Tot mai des, pe la mijlocul anilor '70, Păunescu a urcat poezia (și pe a lui, și pe a altora) pe scena Cântării României. Mici acte de curaj politic au fost compromise de mari lașități, iar pretenția de adevăr a fost copleșită de reverențe scabroase făcute dictatorului și regimului. [...] Există la el poezii admirabile care riscă să treacă neobservate din cauza ideii preconcepute (dar cât de apăsat consolidate de autorul însuși!) că, de la Istoria unei secunde încoace, Adrian Păunescu a devenit un poet monocord, emfatic și fastidios, necinstit cu cititorii și cu arta sa") (Manolescu, Istoria... 1952). Instead, the expansive patriotism, in verses such as "For the people and for Romania / We still do not pay the entire debts / But we're still her sons at any moment" („Pentru popor și pentru România, / Tot nu plătim întreagă datoria, / Tot fiii ei sîntem în orice vreme") gives the tonality of a parade poem, reiterated in previous volumes.

After the registry changes from 1971, the poet's rhetoric doesn't modify too much, until the apparition of Manifest for the ground's health / Manifestului pentru sănătatea pământului (1980). From the title alone, it is presented as a volume pledged against a predetermined order, questioning the "ill" social reality: "He judges time and judges himself without considerations, warns, confesses. He does not protest: it's intransigent. And he doesn't want to convince, to demonstrate, to influence, he names exactly with sharp and icy ease, the evilness of which eternity and he suffer of: " The happiest gloomy » is a lucid diagnostician who doesn't hide himself. Despite the offensive title, this volume is an austere book about the epoch's diseases and about the dramatic effort of contemporary man to overcome them" („Ị̂și judecă timpul și se judecă pe sine fără menajamente, avertizează, mărturisește. Nu protestează: e intransigent. Și nu vrea să convingă, să demonstreze, să înrîurească: numește exact, cu o dezinvoltură tăioasă și glacială, răul de care suferă veacul și el însuși. «Cel mai vesel mohorât » este un diagnostician lucid care nu-și ascunde propria-i fișă. În ciuda titlului ofensiv, volumul este o carte austeră despre maladiile epocii și despre efortul dramatic al omului contemporan de a le depăși”) (Iorgulescu, „Adrian Păunescu, poetul” 12). Literary criticism remarks the changes in writing, so that it still makes an "event book, not theatrical, not at all grandiloquent" volume. 
Immediately after the mentioned volume, Păunescu's two front game expanded in a way that the texts integrated in analogies or the books in final edition were distanced from the poems of periodic publications. Still, in Manifest..., the poet didn't entirely give up on historical coordinates or legitimate narratives as Miorița (Miorița săracă), which he situates in a mythical past, of liberal Dacia and Zamolxe. If in Repeatable charge / Repetabila povară, the present coincides with a moment of national awakening, in which the new world describes a space and time of common good, then in Manifest for the ground's health / Manifest pentru sănătatea pământului, the entire century is affected by "mother-dead", in a significant overturn, in anti-thetic terms, of the "motherland": "We are the sons of a diseased century / We are the cancerous elite / We won't be cured with any pills / Poor Iovi on a forgotten planet / [...] / We want life for those whom we birthed / We want life for us, who are alive, / For death works silently in us / Right now, as we speak about life” („Noi suntem fiii veacului bolnav / Noi suntem canceroșii de elită / Nu ne mai vindecăm cu nici un praf / Bieți Iovi pe o planetă parasite / [...] / Vrem viață pentru cei ce i-am născut / Vrem viață pentru noi, aflați în viață, / Că moartea chiar în noi lucrează mut / Acum, când noi vorbim despre viață" (Păunescu, Manifest... 201).

From Alex Ștefănescu (Ștefănescu, „Despre Adrian Păunescu” 12) to Laurențiu Ulici (Ulici, Confort Procust 46), literacy critiques discuss Manifest for the ground's health / Manifestul pentru sănătatea pământului in praising terms. All the changes in the position of the exegesis take place, after all, only after the 1989, based on re-discussing Păunescu's poetry on ethical coordinates, of "reframing" poetry in the new political context. After 1981, the texts from volumes distanced themselves from the periodic ones. While the latter continue an eulogistic path in the direction of the regime and the leader, a poem such as Greetings from Atlantida / Salutări din Atlantida, from the Make love on cannons / Iubiți-vă pe tunuri volume, permits the building of a fictional motherland with a provoking language: "Greetings from Atlantida, greetings from the country of dead /... How are your kids doing? Your uncle? Auntie? What about the tyrants? / By the way, regarding liberty - How's the parliament been holding? / Greetings from Atlantida, we don't receive condolences / Greetings from an infernal death, a quiet and submersed inferno / What have you been doing outside, that not even the shadow is visible / Unless maybe a shadow crammed in embers?” (,,Salutări din Atlantida, salutări din țara morții /... Ce mai fac copiii voștri? Unchiul? Tanti? Dar tiranii? / Apropo de libertate - Parlamentul ce mai face? / Salutări din Atlantida, nu primim condoleanțe / Salutări din iadul morții, 
iad tăcut și subacvatic / Ce mai faceți voi pe-afară, de nici umbra nu se vede / Decât poate ca o umbră îmbâcsită în jăratic?") (Păunescu, Manifest... 773).

It's exactly this visible subversion, lacking censorship, expanded in opposition with pathetic and militant texts from literary magazines that subdued the poetry after 1981 to a couple of investigations regarding historical truth. The first premise which is meant to explain the dissonances, say that the poetry from the volumes are the results of a compromise with censorship, which permits a continuity of these texts, in order to maintain the illusion of liberty, of writing. Corina Croitoru issued the assumption that censorship functions randomly in picking his poetry, which explains the chance of apparition of a much more incisive poem, much more aggressive towards dictatorship, than the ones from the volume entitled Censored poetry / Poezii cenzurate, published in 1990. But verses such as: "May the tricolor be in dignity / As it is the only ruler of our country / May the warder stay healthy / The innovating, the explorer / The headspring of our nation" (Trăiască-n demnitate tricolorul / Pe țara noastră numai el stăpân / Trăiască-n sănătate păzitorul / Înnoitorul, descoperitorul / Izvoarelor poporului român") (Păunescu, Manifest... 776) discredits the subversion of Păunescu's poetry in such a way that "oppositional" texts are seen as "blackmail with opposition".

The second premise placed the debated poems under a false sign, in a sense of affirming through denial. Exaggerating in implications, this subversive note turns against it, creating a new ideology through which Păunescu's liberties correspond to general liberties, to a common sentiment which he seems to hold a speech upon. So, his impact over poetry becomes even stronger when he fuels the illusion of liberty in expression and censorship.

In Reservation of bisons / Rezervația de zimbri, just like in the other volumes published before 1990, the imaginary is repetitive, schematic, especially in the way of configuring the relationship with homeland. Although it's very strong in quantity, the theme doesn't cross the boundaries which were already established in latter texts: "Full and unconditional love / I won't give because you give, for I'm yours because I am/ Inside me, the Scythians are indebted still / You, mother, you country, you saintly word” („Iubire deplină și fără condiții, / Nu-ți dau, dacă-mi dai, ci-s al tău fiindcă sînt / În mine datori îți mai sînt încă sciții / Tu mamă, tu țară, cuvântule sfânt") (Păunescu, Manifest... 821). The matrix universe is a land of welfare, protected by history, through heroes of the nation and divinity, to whom the poet becomes a bard, with a messianic vocation, such as the ones from the '48's. Avram Iancu's figure, Eminescu's 
poetry, the village as original space and the childhood as ideal age restore to saturation a regenerating motherland, with identity valences.

Starting with the revolution from 1989, the history of courthouse changed. What had been appreciated as aesthetic in the communist era was suspected as collaborationism and ethic compromise, and the drawer of literature became proof of a firm position before the dictatorship. Furthermore, the predilection for memoirs and journal enrolled in this direction of searching for a historical truth. After a permanently censored era, in which the reality is contaminated by politics' fabrication, those who published under censorship and under Păunescu's pace, gathered attention from the literary world. The changes of aesthetic criteria and aesthetic judgement made the poet decay from grace of the previous period, as he was accused of pact and militancy. Vladimir Tismăneanu, Monica Lovinescu or Mircea Popa disbanded his poetry based on ethical criteria. At the same time, recent critical generations - Paul Cernat, Angelo Mitchievici, Corina Croitoru - also relativized the way of relating to Păunescu's text, in the context of 90's, they pushed the pedal of revolutionary patriotism in the same logic of affirmation by negation.

Ever since the beginnings, the apparition of Censored poetry / Poezii cenzurate (from 1990) raised strong question marks. Had the texts really been censored, or are the volumes trying to save the image of a compromised poet? How subversive are these poems towards the published ones, and what are the criteria for selecting the indexed texts? Why does Păunescu feel the need to justify himself at the end of the volume in two paragraphs, first in Argument, then in Edification? Actually, the excessive justification from Argument, betray, in the end, the volume's authority. Obliged to write a eulogy against the "hooligans" (Păunescu, Poezii cenzurate 758) in 1989, Păunescu declared his courage to oppose against the official desire. In the course of an entire era of dictatorship, triumphant and encomiastic writing in part of his poetry, he declined political implications in the attempts of falsifying the historical truth and reframing his poetry, outside of any previous concessions.

Through an "autonomy of mystification" (Cernat, În căutarea comunismului pierdut 265), Păunescu seeked to enforce an "immaculate" figure after 1989, for posterity, through censoring previous verses, and triumphant and eulogistic declarations removed from volumes and kept only in the previous ones. Like this, texts don't suffer only dictatorship censor, but they are also selected by the poet according to the purpose of publishing them. A poem such as Greetings from Atlantida / Salutări din Atlantida isn't less innocent than The dirt flag / Steagul de țarină: "I have no contract with anyone but this country / I love 
the peasants and houses in the villages, / The demented disintegration kills me, / And I think it's absurd and I think it can't be" (Păunescu, Poezii cenzurate 77). The insulting attitude, the exaggerated revolt and the expanded rhetoric accuse the mood in equal measure. As Corina Croitoru observed, a part of the previous poems is presented as censored and less aggressive than the ones published in the years of dictatorship, as they sometimes use Aesopian language, absent in the previous poems. Publishing the volume of censored poems right after the change of the historical courthouse and the poeticism criteria, along with the competition of subversive nuances from the visual texts, make Păunescu's Censored poetry / Poezii cenzurate a volume which is part of the self-proclamation process.

Regarding patriotic poems, at the level of imaginary, they are built based on the descendance of those before 1989. The village, the elders and the 48 's predecessors contribute to the consolidation of a specific rhetoric. Still, if the poetic attitude in the published volumes was rather a pathetic and declarative one, the high tonality and the revolutionary pathos gain priority: "The national cause deserves everything / including the battle for / national prosperity. / Too many took the national cause / as a shield against / natural need of the citizen. / [...] / For the national cause / everything must be done / even something for the nation” („Cauza națională merită totul / inclusiv lupta pentru/ prosperitatea națională. / Prea mulți au luat cauza națională / drept pavăză împotriva / nevoilor firești ale cetățeanului / [...] / Pentru cauza națională / trebuie făcut totul / chiar și ceva pentru națiune") (Păunescu, Manifest... 243-44). Similar to the poems from his first volumes, the patriotism takes the form of nationalism, with the difference that, while in the volumes of 1971 nationalism was in accord with official ideology, in the censored poems they are included in the expressions of citizen nationalism, built not in agreement with the communist ideology, but with the folklore ideology. Likewise, Pray for Romanian people / Ruga pentru poporul român isn't necessarily a text against the regime, but against a certain opression: "People born loving without hate / People who grind, people who endure / Their being remains historical and pure / For the Romanian who steals, steals by instinct” („,Popor născut iubirii și fără nici o ură / Popor care trudește, popor care îndură / Ființa lui rămâne istorică și pură / Că de la sine fură românul care fură") (Păunescu, Manifest... 357).

Without adding specific aesthetics to Păunescu's work, the censored patriotic poetry, in the logic of the entire volume, is important rather as a historical document of a controversial era, situated under the sign of truth and the redistribution of literature based on ethical criteria. Far from considering 
him, like Ion Rotaru, a "poet of truth" (Rotaru, Prefața... 12), Păunescu is the poet who sets himself up for failure, who assumes each limited gesture that keeps him in the politics or literature world. Certainly, a character of contrast, which "ambitious to be, at the same time, the most prolific bureaucrat poet, and the loudest contender, a seismograph of Romania's destiny” („care ambiționa să fie, în același timp cel mai prolific poet de curte și cel mai gălăgios contestatar, un seismograf al destinului României") (Cernat, În căutarea comunismului pierdut 262), Păunescu forms an unremorseful actor on a scene he builds in permanence. His appeal to patriotic themes, to odes or anthems as specific modalities of expression, takes part of the inculcating process upon an obedient feeling, which makes reality tolerable.

Despite the many volumes published after 1990, Păunescu's poetry becomes citizen oriented, shallow, which doesn't astonish as imaginary or stylistic: "It's obvious that patriotic poetry must direct its readers towards national myths, not estrange them from it. But the criteria remain the one of aesthetic relevance. When the images are too cliched, former metaphors crammed through an elongated usage (country: « a grain of wheat in the rut of a century »), poetry becomes simple speech, where the form tends to substitute the fund. When on the contrary, in old typography, the poet innovates and does not crush his imaginary force, the results are extremely good, aesthetically speaking, but the clarity of the message risks to be lost” („Este evident că poezia patriotica trebuie să-și direcționeze cititorii către miturile naționale, nu să-i îndepărteze de ele. Dar criteriul rămâne cel al relevanței estetice. Când imaginile sunt prea clișeizate, foste metafore tocite printr-o folosință îndelungată (țara: « un bob de grâu în brazda unui veac »), poezia devine simplu discurs, forma tinde să substituie fondul. Când, dimpotrivă, pe vechile tipare poetul inovează și nu își mai încorsetează forța imaginativa, rezultatele sunt foarte bune, estetic vorbind, însă claritatea mesajului riscă să se piardă") (Cristea-Enache 12).

Compared to the patriotic poetry before 1990, Păunescu's motherland meets no geographic delimitations. Poetry as an event, in the sense of occasional text defined by Predrag Matvejevic is Păunescu's works. This paper insisted on the modifications suffered by Păunescu's patriotism according to the periods of time he had to adopt to. Always engaged, the poet reframed history and used patriotism to survive on the changes of the historical tribune. When he's unfairly disputed and removed from the scene of major literature, when overappreciated until mythification, the poet is programmatically a character of extremes, an expansive figure, present with the price of imaginary and image exhaustion, in all scenes of history. 


\section{Works Cited}

Cărtărescu, Mircea. „Păunescu: un odios propagandist” (Păunescu. A detestable propagandist), Ziare.com, 2010: <http://www.ziare.com/adrianpaunescu/cenaclul-flacara/mircea-cartarascu-paunescu-un-odios-propagandist1056680>.

Cernat, Paul. In căutarea comunismului pierdut (Looking for the lost Communism), Pitești: Ed. Paralela 45, 2001.

Cristea-Enache, Daniel. „Râul, Ramul...” (The River, the Branch), Cultura, n. 53, 2016.

Croitoru, Corina. Politica ironiei în poezia românească sub communism (The policy of irony in romanian poetry under the Communism). Cluj-Napoca: Casa Cărții de Știință, 2014.

Iorgulescu, Mircea. „Adrian Păunescu, poetul” (Adrian Păunescu, the poet), România literară, 22 ianuarie 1981.

Iorgulescu, Mircea. Scriitori tineri contemporani (Contemporary young writers). București: Ed. Eminescu, 1978.

Lovinescu, Monica. Posteritatea contemporană. Unde scurte (The contemporary posterity. Fleeting waves), vol. III. București: Ed. Humanitas, 1994.

Manolescu, Nicolae. Istoria critică a literaturii române (The critic history of Romanian literature). Pitești: Ed. Paralela 45, 2008.

Matvejevic, Predrag. Poetica evenimentului. Poezie și angajare (The lyrics of the event. Poetry and politic engagement). București: Ed. Univers, 1980.

Moraru, Cornel. Semnele realului. Secționări critice convergente (The signs of real. Critical convergent sections), f.l.: Ed. Eminescu, 1981.

Păunescu, Adrian. Istoria unei secunde (The history of a second). București: Ed. Cartea Românească, 1971.

Păunescu, Adrian. Manifest pentru mileniul trei (Manifesto for third millennium), vol. I. București: Ed. Eminescu, 1990.

Păunescu, Adrian. Poezii cenzurate (Censored poems). București: Ed. Păunescu, 1990.

Pop, Ion. Lecturi fragmentare (Fragmented readings). București: Ed. Eminescu, 1983. Popa, Mircea. Prezențe literare. Oameni și cărți (Literary presence. People and books), Cluj-Napoca: Ed. Casa Cărții de Știință, 2011.

Rad, Ilie. „Am avut dintotodeauna obsesia apartenenței naționale și a identității” (I always had the obsession of being a part of the nation), Tribuna Cultural Journal, $\mathrm{n}$. 192/ 9, 2010.

Rivette, Jacques. „De l'abjection” (About Abjection), Cahiers du cinéma, n. 120, 1961. 
Ștefănescu, Alex. „Despre Adrian Păunescu” (About Adrian Păunescu), România literară, 2 aprilie 1981.

Tismăneanu, Vladimir. „Menestrelul comunismului dinastic sau cine a fost Adrian Păunescu" (The slave of the dynastic Communism or who was Adrian Păunescu], in Contributors.ro, 5 noiembrie 2011, http://www.hotnews.ro/stiriopinii-8008457-contributors-context.htm.

Ulici, Laurențiu. Confort Procust (Procust Confort). București: Ed. Eminescu, 1983. Viroli, Maurizio. Din dragoste de patrie. Un eseu despre patriotism și nationalism (Because of the love of country. An essay about patriotism and nationalism), translated by Mona Antohi. București: Ed. Humanitas, 2002. 